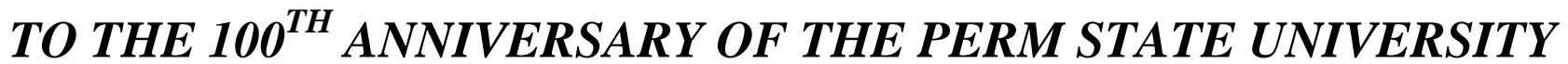

doi 10.17072/1994-9960-2016-2-32-53

UDC 657:338.2

LBC 65.9

\section{PROBLEMS OF ACCOUNTING, ANALYSIS AND CONTROL IN MANAGING AN ENTERPRISE'S PRODUCTION AND FINANCIAL RESOURCES IN THE CONTEXT OF ECONOMIC PROCESSES GLOBALIZATION}

\author{
T.G. Sheshukova, Doctor of Economic Sciences \\ E-mail: sheshukova@psu.ru \\ Perm State University; 15, Bukireva st., Perm, 614990, Russian Federation
}

In Russia there has always been a very effective system of schools of thought, playing an important role in social development. They produce, propagate, defend scientific ideas and train young scientists at the same time. To review theoretical and practical results achieved by the school of thought at the Department of Accounting, Auditing and Economic Analysis. The review covers the period of 2005-2015. Attention is focused on the analytical problems of theory and practice in business management, registration aspects of managing production and financial resources, problems of theory and methods in the development of auditing and control. The research is aimed at: formulating theoretical provisions and practical recommendations for fiscal and management accounting development; functional and analytical representation and generalization of theoretical foundations for the system of auditing activity regulation as well as analysis of directions for its further development; improving methods of economic potential analysis on the basis of the component approach to its integral assessment; constructing theoretical and methodological bases to bring the Russian financial statements in accordance with the international standards. The researches are based on the economic theory provisions, fundamental concepts of philosophy, social hypotheses. The system complex approaches, analysis and synthesis, induction and deduction, economic-mathematical modeling and programming, statistic methods and methods of sociological researches were applied. The school of thought has developed theoretical and methodical provisions to use and develop the fiscal accounting mechanism and the system of management accounting taking into consideration organizational and economic characteristics of enterprises and organizations operating in the fields of oil products supply, electrical engineering and agriculture; bases for the analysis of an economic entity's economic potential; bases for structural transformation of the main forms of financial statements according to the international standards; a model of the quality-oriented system of auditing activity regulation. Conclusions on theory and methods specify and develop the existing concepts of accounting, analysis and control. The research results can be applied in many spheres, they have been presented at conferences and introduced into the training process.

Keywords: school of thought, strategic analysis, assessment of economic potential, fiscal and management accounting, tax accounting and control, International Financial Reporting Standards, forensic accounting, commercial calculation, auditing, control.

\section{Introduction}

Since the antiquity a school of sciences plays an important role in society. Now in connection with a rapid progress of science the role of school of sciences considerably increased.

We review the theoretical and practical results received within school of sciences of "Accounting, Audit and Economic Analysis" department. The review covers the period from 2005 to 2015. There are following directions of scientific researchers:
1. Accounting problems of production and financial management of enterprise;

2. Research of actual analytical problems of business management, commercial calculation, assessment of economic capacity of the enterprise;

3. Theoretical and methodical aspects of development of audit and control.

The founder of school of sciences is Sheshukova Tatyana Georgiyevna - professor of department of accounting, audit and the economic analysis (from 1992 to 2015 she was a head of this 
department); Doctor of Economics, professor; member (academician) of the International academy of Sciences of the higher school; honored worker of the higher school of the Russian Federation. She is the member of the joint dissertation council of DM 212.188.09 on the basis of "The Perm national research polytechnic university" and "The Perm state national research university"; honorary member of institute of professional accountants of Russia; president of the Perm territorial institute of professional accountants and auditors; the permanent member of jury of the AllRussian review competition of theses in "Accounting, the analysis and audit"; honorable professor of "West Ural Institute of Economy and Right"; member of an academic council "The Perm national research university". In 2011 the Russian academy of natural sciences gave to Sheshukova Tatyana Georgiyevna an honorary title of the founder of school of sciences "accounting, analytical, control problems of production and financial recourses management in the conditions of globalization of economic processes" (the certificate No. 00412 (on January 25, 2011).

Leading scientific schools: M.A. Gorodilov, Dr. Econ. Sci., associate professor; S.V. Pankova, Dr. Econ. Sci., professor; L.S. Sosnenko, Dr. Econ. Sci., professor; S.V. Ponomareva, Cand. Econ. Sci., associate professor; O.A. Rybalko, Cand. Econ. Sci., associate professor; T.V. Pashchenko, Cand. Econ. Sci., associate professor; A.V. Posokhina, Cand. Econ. Sci., associate professor; K.Yu. Kotova, Cand. Econ. Sci., associate professor; E.B. Nikitina, Cand. Econ. Sci., associate professor; D.V. Orlov, Cand. Econ. Sci., senior lecturer; K.V. Razuvayeva, senior lecturer; A.V. Beresneva, teacher [34].

The most significant projects in the sphere of basic researches executed within school of sciences:

1. "Formation of information and communication competence of graduates of classical university according to requirements of information society" (2004-2007). National Education project Ministry education and sciences of the Russian Federation.

2. "The best accountant of Perm Krai". Joint project with the Perm territorial institute of professional accountants and auditors (2005-2015).

3. "Forecasting of registration and analytical and control system of innovative development of territories in the conditions of globalization of economic processes", realized within a scientific and educational complex (NOK-4) "Forecasting and management of processes of social and economic development of the countries and territories on the basis of modern information technologies" (2010-2019). National project. Ministry of Education and Science of the Russian Federation.

The most significant projects in the sphere of applied researches are executed for JSC Kamkabel, RFOO "PITTs Geophysics", JSC Magistral-trade Trading House, JSC Stroyindustriya, JSC Lukoil Oil Company, JSC NPK Energiya, JSC Energosbyt (Perm), JSC Perm Research and Production Instrument-making Company, the West Ural Bank JSC Sberbank of Russia (Perm) and others.

1. Theory and history of development of methodology and organization of accounting

In modern Russian economy accounting becomes an invaluable source of information for management and owners of the organization when forming expenses and prices for products for the purpose of high-quality and comprehensive control of use of non-current and current assets, definition of opportunities of investment. All this, finally, defines competitive opportunities of the organizations in a domestic and foreign market. The purposes which are legislatively established before accounting and tasks cover area of financial, management accounting and tax accounting.

Improvement of the accounting of fixed assets in the conditions of automation of a control system. Continuous growth of requirements from managers and owners to the effective organization of registration process in the sphere of use and disposal of fixed assets, especially at an assessment of opportunities of increase of level of production due to its re-equipment with the new highperformance equipment, forecasting of financial results of activity for the purpose of prevention of financial risks, causes the growing theoretical and practical interest in a problem of improvement of accounting of fixed assets [16].

Theoretical and methodical provisions on improvement of the mechanism of the financial accounting of fixed assets in the organization by means of formation of the accounting tools allowing to organize uniform system of an operating control and management accounting for the purpose of prevention of financial risks and ensuring financial stability in the conditions of an automated control system for the organization are developed and proved.

The approach to the organization of the financial accounting of gratuitous receipt of fixed assets allowing on the basis of carrying out a comprehensive market assessment of property taking into account the expenses made by the organization independently, and improvement of an order of reflection of the specified operation on 
accounts of accounting in the conditions of an automated control system with use of the created analytical table is defined to create information base for the account and control of property and formation of the income of the organization according to Accounting regulation 9/99 "The income of the organization".

According to Accounting regulation 6/01 the fixed assets received by the organization gratuitously are considered at the initial cost determined as their current market value at the time of acceptance into accounts of accounting as noncurrent assets. The current market value has to be determined by the organization independently.

For determination of the specified size the organization has to compare suggested prices on same (or similar) to goods in comparable conditions. Determination of the price on the basis of statistical or expert data, data of manufacturers is possible. Thus it is necessary to consider that the data received from various sources can differ significantly from each other that influences determination of the size of tax base on the property tax and is capable to lead to emergence of the tax risks connected with additional accrual of the property tax, income tax.

The developed analytical register allows automating the specified operation, to consider data of various sources when forming and to involve in its performance of the specialists of the organization having sufficient knowledge of $\mathrm{dl}$ of determination of market value. Application of such analytical register will allow avoiding financial risks, authentically to create the initial cost of the fixed assets arriving gratuitously without double accounting of expenses on delivery and installation.

The existing system of acquisition of fixed assets doesn't reflect economic essence of gratuitous receipt of fixed assets and real data on financial results of activity of the organization.

The recommended scheme of accounting records:

- The debit 08 "Investments in noncurrent assets" Credit 91 "The other income" - on the market value of the main means received under the contract of donation (gratuitously) at the time of its receipt.

- The debit 08 "Investments in noncurrent assets" the Credit 10,23,25,60, etc. - for the sum of additional expenses on finishing it to a state in which the object is suitable for use.

- The debit 01 "Fixed assets" the Credit 08 "Investments in non-current assets" - at input of object of fixed assets in operation.

Thus the condition of surely has to be satisfied that the cost of objects of the fixed assets received gratuitously (except for additional costs of finishing them to a state in which they are suitable for use) isn't subject to depreciation.

Within the operating system of the financial account approach and a technique of creation of information base of the capital construction which is carried out in the contract way, allowing to provide automatic formation of accounting records, information base of management accounting and the organization of an operating control behind an expenditure of funds for capital construction for the purpose of prevention of financial risks from unplanned expenses are formulated.

Today the system of accounting of capital investments doesn't provide control of execution of estimates of costs of construction of facilities, identification of level of deviations of the actual expenses from estimated cost of construction. It not only leads to weakening of control functions of the account, but also promotes education in accounting of fictitious construction objects.

The existing system of the account isn't able to provide to the user to operate the size of capital expenditure and to trace them. In practice of costs of construction of facilities, approved and coordinated in estimates on construction, don't coincide with the actual costs of their acquisition that can lead to essential changes in the budget of the organization, destruction of strategic plans of the organization and, perhaps, to financial risks.

It is expedient to involve sub-accounts of book of accounts:

08-3-1 "Construction of facilities of fixed assets. The expenses are covered by the estimate".

08-3-2 "Construction of facilities of fixed assets. The expenses are not covered by the estimate".

In the conditions of an automated control system for the organization for simplification of work of accounting service and avoidance of the mistakes caused by a human factor the register of the analytical account "Control of expenses on construction of fixed assets" At application of the specified analytical register is offered automatically (in a program complex) accounting records and warnings of a deviation of the actual costs of construction from the budget are formed.

The similar system of the account allows the user to see deviations of actually made and planned expenses, to estimate their importance, to establish the reasons of divergences, dividing them on proved (rise in price coefficients (inflations and replacements of materials, the equipment, etc.) and unreasonable (increase of rate of return of the contractor), to prevent economic crimes, such as "kickback", "bribery", etc., easily 
and quickly to compare costs of building of similar objects in time.

The principles of charge of depreciation charges in the way of the reducing rest allowing reflecting real information on decrease in consumer functions of the equipment in accounts of accounting are defined.

The way of the reduced rest assumes that efficiency use of objects of fixed assets each next year below, than in previous as the resource of operability of fixed assets is gradually settled.

When using a way of the reduced rest the annual sum of depreciation charges is defined proceeding from a residual project cost of fixed assets and norm of depreciation. The norm of depreciation, in turn, is defined proceeding from useful service of the basic and the coefficient established not higher than 3 . The coefficient is defined by the organization independently. Application of a certain coefficient has to be fixed in accounting policies.

$$
R d=\frac{1}{U} x K,
$$

where Rd - rate of depreciation, $\mathrm{U}$ - the expected useful life of the object, $\mathrm{K}$ - special coefficient.

The coefficient $\mathrm{K}$ is established in the range of more than 1 and up to 3 inclusive.

$$
A D=R V \times R d,
$$

Where AD - the annual amount of depreciation, RV- the residual value of the asset. Thus the monthly sum of depreciation is defined as $1 / 2$ annual sums of depreciation.

Application of this method accurately coordinates with moral concept and also physical wear of concrete object as it annually loses the consumer properties with simultaneous reduction of residual cost.

The approach to an assessment of an obsolescence and determination of need of replacement of the outdated equipment by more productive considering depreciation of the used equipment, requirements of the tax law and the defining effect from carrying out such replacement is developed.

Theory and practice of development of management accounting

On the basis of the analysis of scientific views of foreign and Russian scientists the principles of management accounting for the enterprises of electro technical branch are specified, also offered in addition to existing: principles of coding of information, safety, quantitative definiteness of degree of uncertainty and risk. Allocation and introduction of these principles is necessary for carrying out the plan fact of the analysis of performance of budgets, different assessment of risks (political, currency, economic, etc.) at adoption of administrative decisions, reductions of risk of emergence of mistakes owing to influence of a human factor. The offered specifications allow to expand theoretical ideas of the contents and group of the principles of management accounting [20; 32; 33].

The branch factors influencing functioning of system of management accounting of expenses in the organizations of electro technical branch (tab. 1) which account is necessary for statement and definition of the priority directions of development of management accounting at these enterprises are revealed. Influence external (economic, social, universal) and internal (branch features of production, structure of products, technology and type of production) factors on the organization of system of management accounting is analyzed.

Table 1

The factors influencing the organization of management accounting at the enterprises

\begin{tabular}{|c|c|c|c|}
\hline Factor & Description & Exemples & Influence on management accounting \\
\hline \multirow[t]{6}{*}{ Internal } & \multirow{6}{*}{$\begin{array}{l}\text { Technical } \\
\text { features of } \\
\text { electro tech- } \\
\text { nical indus- } \\
\text { try }\end{array}$} & Product materials consumption & The need for planning and control of material resources \\
\hline & & $\begin{array}{l}\text { Significant amounts of work in pro- } \\
\text { gress }\end{array}$ & $\begin{array}{l}\text { Work in progress becomes an object of accounting. } \\
\text { There are the issues of selection the right method of } \\
\text { work in progress assessment }\end{array}$ \\
\hline & & $\begin{array}{l}\text { The resources can't be allocated to } \\
\text { some particular place of production }\end{array}$ & $\begin{array}{l}\text { Issues of selection the methods of allocating indirect } \\
\text { costs }\end{array}$ \\
\hline & & $\begin{array}{l}\text { There is a need to create a compa- } \\
\text { ny’s own maintenance and auxiliary } \\
\text { production }\end{array}$ & $\begin{array}{l}\text { Need of cost accounting (using the following accounts } \\
20 \text { "Main production", } 23 \text { "Auxiliary production", } 29 \\
\text { "Service industries". The problem of choosing the } \\
\text { method of distribution and redistribution of maintenance } \\
\text { and support costs of production }\end{array}$ \\
\hline & & A lot of integrated cost items & Additional details of overhead costs \\
\hline & & $\begin{array}{l}\text { Using outsourced services during } \\
\text { production process (tolling pro- } \\
\text { cessing of raw materials) }\end{array}$ & $\begin{array}{l}\text { The need for information regarding the material costs of } \\
\text { the materials in the warehouse and materials transferred } \\
\text { to recycling to outsourced company. To calculate the } \\
\text { cost of finished goods it is necessary to take into account } \\
\text { the costs of outsourced company }\end{array}$ \\
\hline
\end{tabular}
of electro technical branch 
The end of table 1

\begin{tabular}{|l|l|l|l|}
\hline Factor & Description & \multicolumn{1}{|c|}{ Exemples } & \multicolumn{1}{c|}{ Influence on management accounting } \\
\hline \multirow{2}{*}{} & & $\begin{array}{l}\text { Multi-step production (multiple } \\
\text { stages of production) }\end{array}$ & $\begin{array}{l}\text { Delimitation of the production costs through different } \\
\text { accounts 10, 21, 43 }\end{array}$ \\
\cline { 3 - 4 } & The diverse nature of products & $\begin{array}{l}\text { Registration and calculation of the cost of various types } \\
\text { of products, accounting for the business segments, de- } \\
\text { termining the profitability of individual products }\end{array}$ \\
\hline \multirow{2}{*}{ External } & $\begin{array}{l}\text { Economic, } \\
\text { political, } \\
\text { social, global } \\
\text { factors }\end{array}$ & The high level of competition & Strategic planning \\
\cline { 3 - 4 } & Prices depend on the market & $\begin{array}{l}\text { The need for an operational analysis of the deviation of } \\
\text { actual costs from the plan; market monitoring }\end{array}$ \\
\cline { 3 - 4 } & The seasonal nature of demand & The need of budgeting \\
\cline { 3 - 4 } & The high degree of financial risk & Cash Flow Planning \\
\hline
\end{tabular}

Taking into account branch features objects of management accounting of expenses (a place of emergence of expenses are defined; centers of responsibility; types of the made production), the integrated approach to allocation of the centers of responsibility at the enterprise combin- ing features of functional, factorial and structural approaches that gives the chance of the analysis of structure of expenses both in a section of elements of expenses, and in a section of types of the made production, and also in a section of sites [35] is offered.

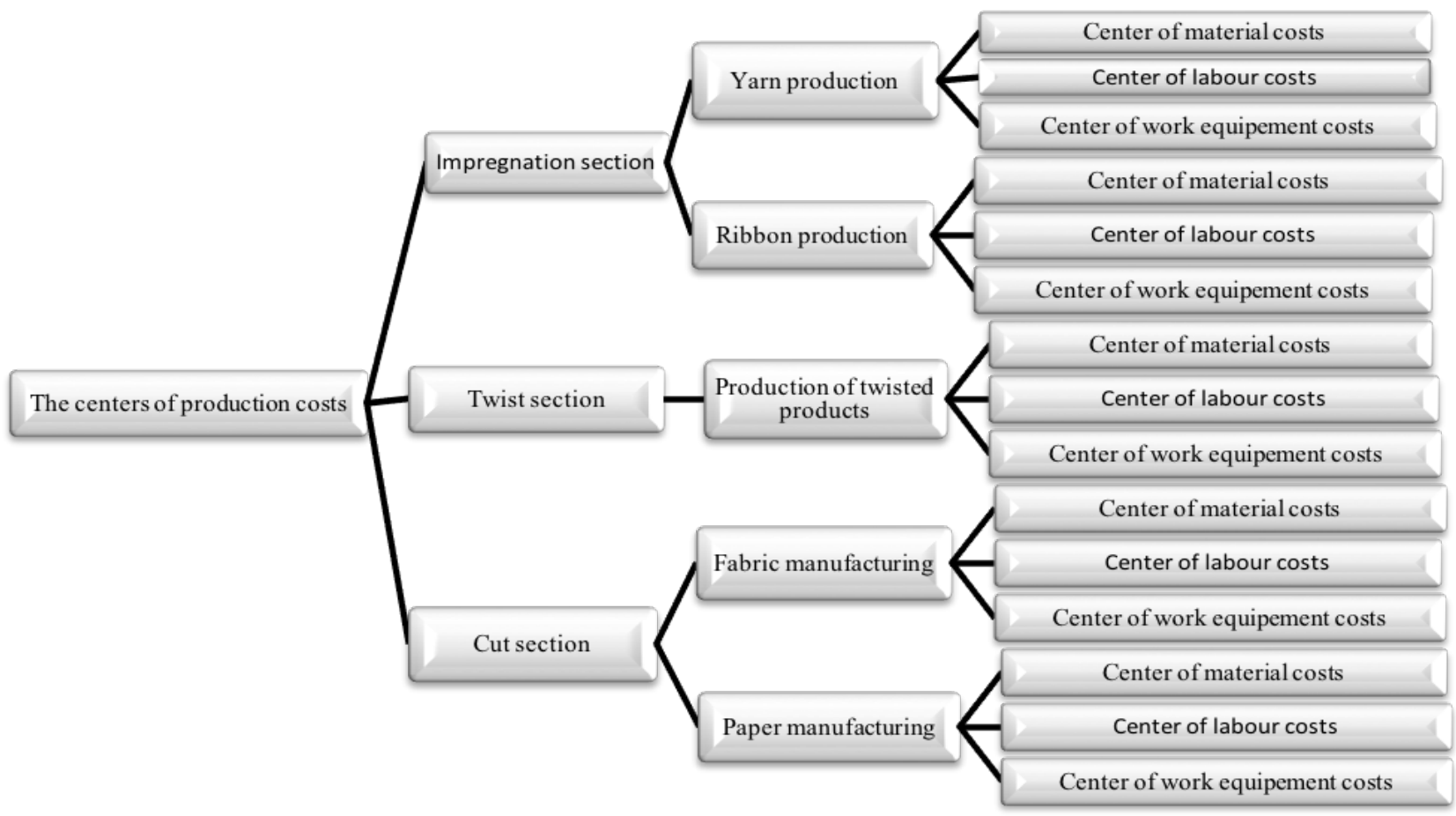

Fig. 1. The offered centers of production expenses for the enterprises of electro technical branch

For the purpose of identification of shortcomings and the priority directions of development of management accounting the technique of the analysis of the existing condition of management accounting which distinctive feature is opportunity by means of research of an organizational, technical, scientific component of management accounting in a complex to estimate system of management accounting on economic and not economic indicators [21] is developed.

Taking into account opportunities of use of modern information technologies at the enterprises of electro technical branch for the purpose of automation of the account, creation of multipurpose information base of management of ex- penses and strengthening of impact of control and analytical function of the account the system of the analytical accounting of expenses focused on use of hierarchical system of accounts, subaccounts and analytical accounts is specified; the technique of management accounting of expenses on the basis of 20-29 accounts based on interaction of system, integration, situational, standard, behavioral, conceptual, information approaches is developed. Use of this technique allows to structure expenses and, thereby, to provide users with necessary information.

The offered approach to process of creation of a cost management system is presented in fig. 2. 


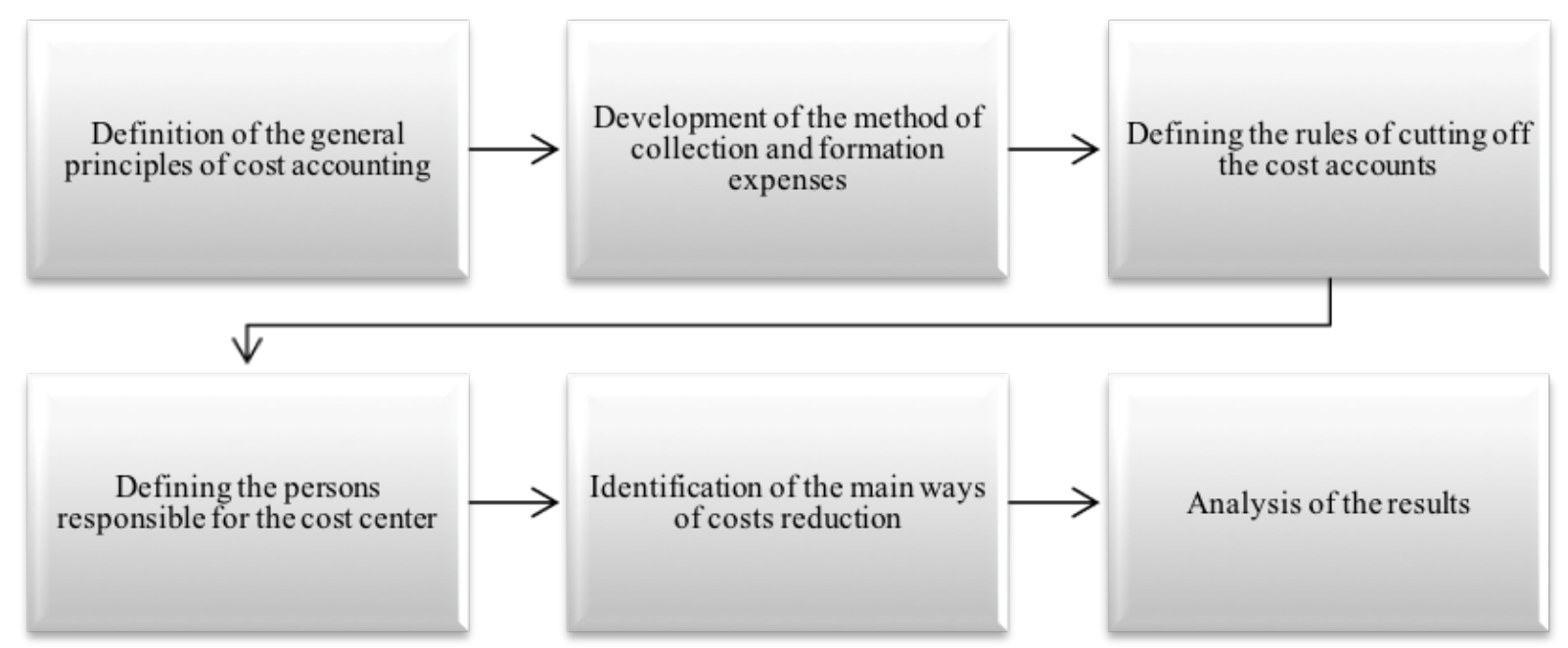

Fig. 2. Process of creation of a cost management system in the organization

On the basis of systematization of the factors defining branch features of creation of system of budgeting from positions of system approach the budgeting technique which allows to exclude duplication of functions by the staff of the enterprises is developed, gives opportunity of expeditious formation of budgets and at realization of the basic principles of planning (complexity, completeness, transparency, flexibility) gives the chance effectively to operate expenses of the organization. Thus the special attention is paid to studying of financial structure of the organization as a fundamental component at allocation of the centers of responsibility and further drawing up budgets at various levels [36].

The important part in system of management accounting is assigned to budgeting. Taking into account the restrictions distinguishing system of budgeting (a kind of activity, strategic objectives, the size of the organization and a control system, information requirements of a key element, volume of demand for production, capacities, availability of raw materials, existence of qualified personnel), the budgeting technique is developed for the enterprises for production of electro technical production (fig. 3).

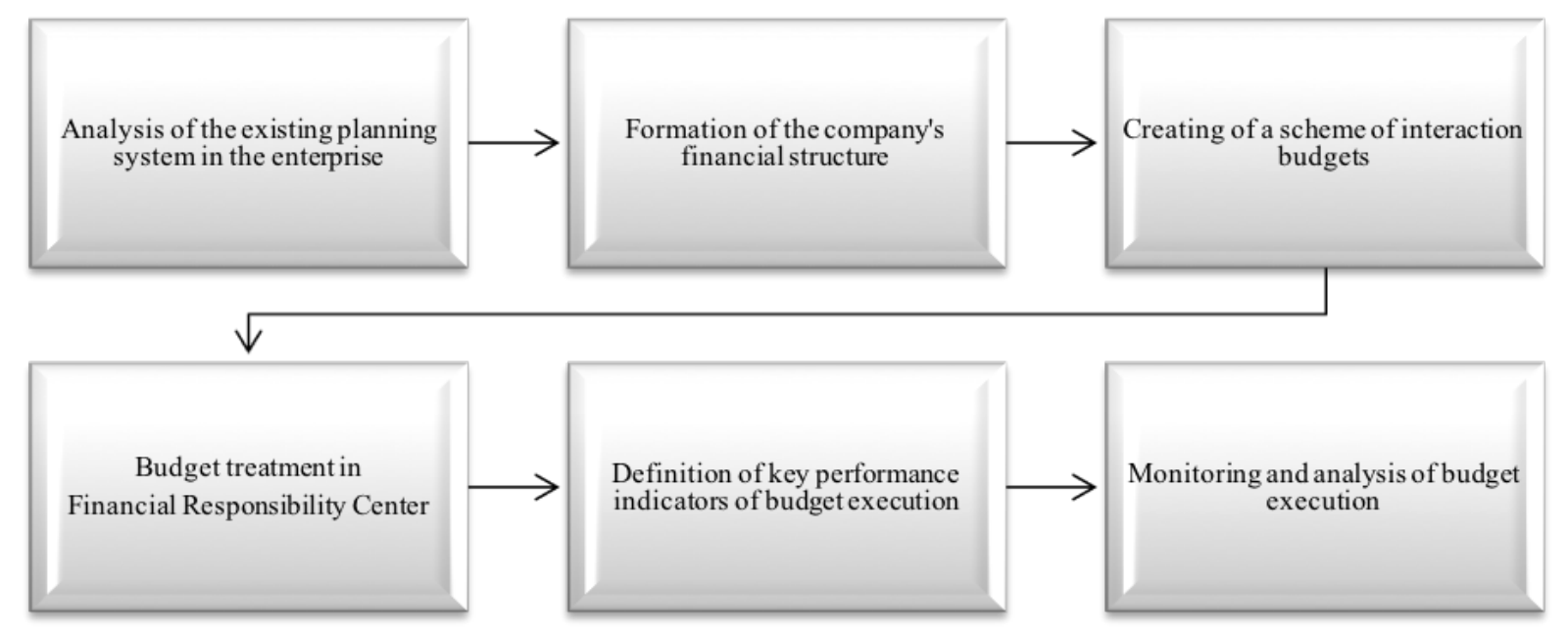

Fig. 3. System of budgeting at the enterprises of electro technical branch

The offered budgeting technique for the enterprises for production of electro technical production allows to provide complexity of system (as budgets are developed at all levels of hierarchy), realization of the principles and flexibility of budgets, the requirement of transparency of information due to specification of items of expenditure and income, carrying out the plan fact of the analysis of deviations for the purpose of identification of an assessment of discipline of the budget, scoping of powers and establishment of responsibility of the head of each division for indicators which can be controlled by it.

In relation to the enterprises of oil products supply (OPS) the integrated system of management accounting founded on interrelation of 
financial and management accounting and answering to the principles of completeness of information, profitability and rationality is developed; places of emergence of expenses and the centers of responsibility are defined; the communication system of places of emergence of expenses and analytical accounts is developed [15].
The developed communication system of places of emergence of expenses (within structural divisions of the enterprise) and the analytical accounts taking into account allocation of groups of expenses is presented in tab. 2 .

Fixing of places of emergence of expenses to analytical accounts

\begin{tabular}{|l|l|c|}
\hline \multicolumn{1}{|c|}{ Expenses } & \multicolumn{1}{|c|}{ Cost centers } & Number of an account \\
\hline \multirow{4}{*}{ Selling and marketing expenses } & Central administrative office & 4401 \\
\cline { 2 - 3 } & Petroleum storage depot & 4402 \\
\cline { 2 - 3 } & Gas station & 4403 \\
\cline { 2 - 3 } & Maintenance centers, wholesale of petroleum products & 4405 \\
\hline Administrative expenses & Central administrative office & 2600 \\
\hline \multirow{3}{*}{ Production costs } & Steam-powered farm & 2301 \\
\cline { 2 - 3 } & Laboratory & 2302 \\
\cline { 2 - 3 } & Management Services & 2303 \\
\hline Ordering costs & Gas station, wholesale of petroleum products & 4404 \\
\hline
\end{tabular}

The technique of distribution of expenses, adequate for branch, in places of emergence of expenses and kinds of activity with closing of expenses on accounts of the financial account and justification of a choice of calculation bases and objects of calculation is theoretically proved, developed and approved.

The indicator "The general and administrative expenses" reflecting specifics of interaction of the managing director and the operated companies and being a basis of control by management company of the expenses directed on needs of business management of OPS and its activity in general is offered. The indicator is a basis of algorithm of planning and collection of information about the actual values of these expenses.

Approach to use within management accounting of information and analytical system of the support of decision-making based on OLAPtechnologies is developed. The structure of the used attributive information for realization of functions of planning, the analysis and definition of expenses is determined by places of emergence of expenses and kinds of activity.

Use mechanism within management accounting of the sliding forecast of liquidity is developed. The basic changes into the system of functional duties of treasurers of the enterprises of branch providing increase of effective management of financial resources at the level of both the separate enterprise, and holding in general are entered, transition to use of a pooling - the perspective bank service directed on effective redistribution of financial resources between the enterprises of holding thereby is provided.

The technology of strategic management accounting including the strategic analysis, a goalsetting, a choice of basic strategy, strategic and expeditious budgeting, formation of system of the strategic administrative reporting, statement of procedures of control and motivation of the personnel is opened. Strategic management accounting represents information technology of identification, collecting and transformation of data on the main tendencies macro- and microenvironments, allowing to position really opportunities and risks of realization of strategy of the organization and on this basis to make administrative decisions on its optimization. The main stages of technology of strategic management accounting are the strategic analysis, a goal-setting, a choice of basic strategy, strategic and expeditious budgeting, formation of system of the strategic administrative reporting, statement of procedures of control and motivation of the personnel (fig. 4) [31]. 


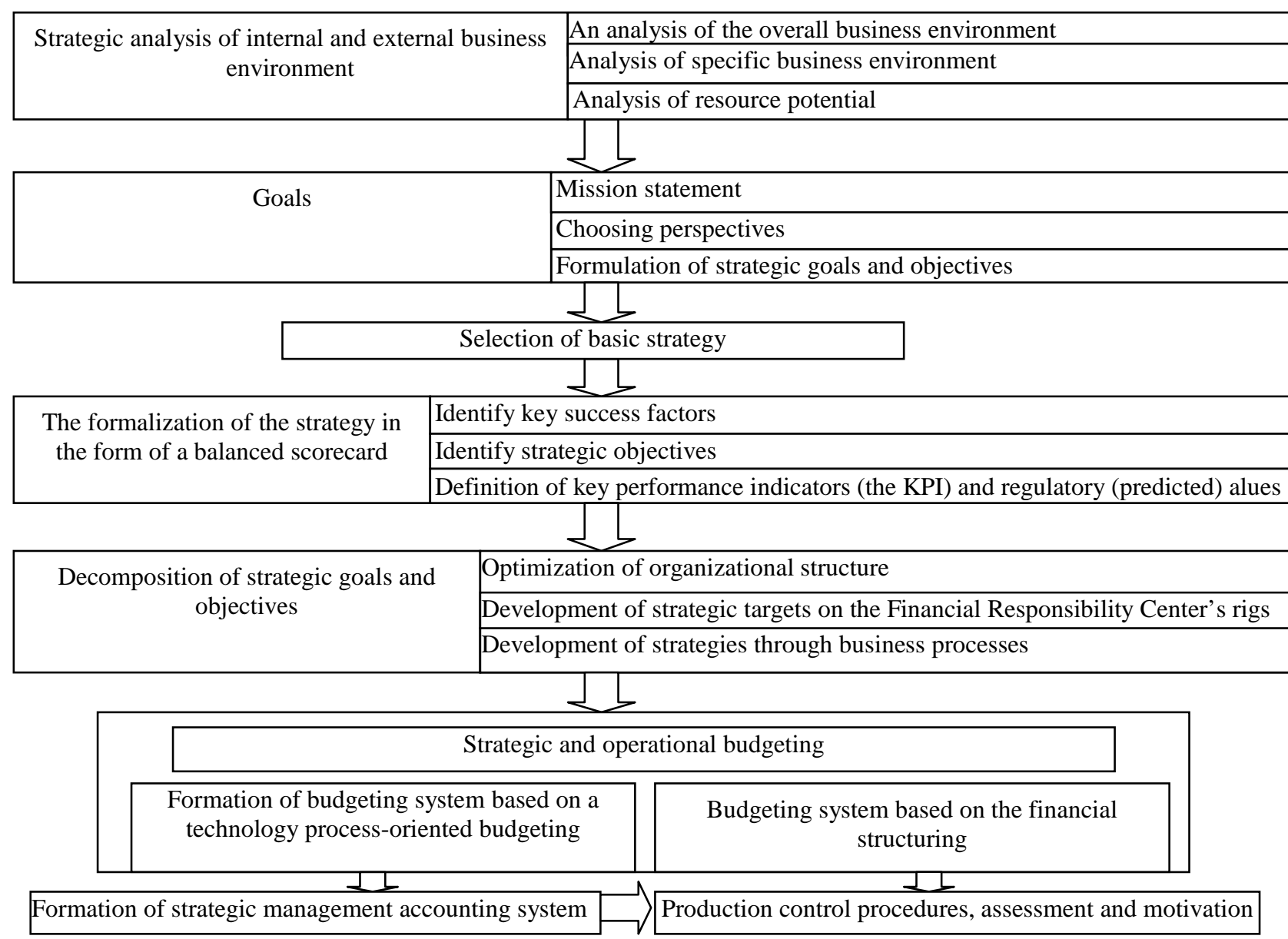

Fig. 4. Interrelation of elements of system of strategic management accounting

For ensuring unity of a theoretical and methodological basis of strategic management accounting the following vision of essence of the basic concepts (tab. 3 ) is offered.

\section{Bases of the modern concept of strategic management accounting}

\begin{tabular}{|c|c|}
\hline Item & $\begin{array}{c}\text { Description } \\
\end{array}$ \\
\hline Perspective & $\begin{array}{l}\text { Prospects of organization development for a period of up to } 5-10 \text { years, representing the totality of the } \\
\text { essential characteristics of the external and internal conditions of financial and economic activities and } \\
\text { its core values }\end{array}$ \\
\hline Mission & $\begin{array}{l}\text { A clear definition of "purpose" of the organization, the best results of financial and economic activity, } \\
\text { based on the goals and objectives of the business and social projects }\end{array}$ \\
\hline Strategy & $\begin{array}{l}\text { Prediction of optimal development of the organization - model to achieve the desired results of the } \\
\text { economic activity with a certain probability of the presence of relevant internal and external business } \\
\text { environment }\end{array}$ \\
\hline Tactics & $\begin{array}{l}\text { Science-based system for making strategic management decisions to optimize current and future de- } \\
\text { velopment of the organization that performs the functions of accounting, control, analysis, motivation } \\
\text { and management of earlier decisions }\end{array}$ \\
\hline Subject & $\begin{array}{l}\text { Science-based system for making strategic management decisions to optimize current and future de- } \\
\text { velopment of the organization that performs the functions of accounting, control, analysis, motivation } \\
\text { and management of earlier decisions }\end{array}$ \\
\hline Object & Economic and financial activities of the organization \\
\hline Method & $\begin{array}{l}\text { The set of methods and techniques of preparation a high-quality information base for making strategic } \\
\text { management decisions, including elements of the method of accounting, methods of economic analy- } \\
\text { sis, economic and mathematical, statistical methods and other methods of identification and transfor- } \\
\text { mation of information flows in accordance with the requests for information in strategic management }\end{array}$ \\
\hline
\end{tabular}

Environment factors with allocation of group of registration quantitative factors of the external near business environment which differ- ence is possibility of a quantitative assessment of influence of a factor on the level of competitiveness of the organization on the basis of registra- 
tion sources are structured, the system of indicators is developed for this assessment.

Theory and practice of tax accounting development.

The periodization of development of tax accounting in the budgetary establishments reflecting key changes which are directed on division of accounting and tax accounting is defined. The interpretation of concept of tax accounting by means of the analysis from positions of requirements of information support is expanded, thus is specified the financial and estimated information and stages showing communication with accounting. At a specification of the theoretical content of concept of the tax accounting which is earlier not considered in special literature the following distributions are made: the functions corresponding to tasks; the principles distributed on stages [29].

For the purpose of identification of operations and formation of the indicators arising during implementation of operations in the innovative sphere in national research university (NRU) the synthesized author's definition of the terms "innovations" and "innovative activity" for tax accounting of income tax is offered. In the last possible channels of receiving innovations and five key stages are considered: creation, development, introduction, commercialization and use realized during implementation of innovative activity.

New approach regarding acceptance to tax accounting of the income, expenses and losses arising during realization of innovative activity is developed. Unlike acting in which the only source of creation of innovations - research and development is specified, the offered approach operates with wider list of sources; classification of the income, expenses and losses by five stages of realization of innovative activity is developed.

Methodical providing is developed for the organization of tax accounting of income tax from innovative activity in NRU. The concept of struc- ture of accounting policies is submitted; unlike existing where the order of the accounting of expenses on research and development is reflected, in the developed the method of recognition of the income, expenses and losses according to stages of innovative activity, an order of their recognition, documentary providing, classification and fixing are presented in registers of tax accounting for the purpose of formation of the reliable sum of income tax. The forms of tax registers reflecting the income, expenses and losses arising in the course of creation, development, introduction of commercialization and use of innovations, and also five reference books necessary for their formation are offered. Analytical indicators on the basis of which the conclusion about documentary discipline, literacy of workers and automation of tax accounting of innovative activity is formulated are developed.

The system of indicators, and also technique of their reflection in the tax declaration on income tax is created and proved. Unlike accepted in the offered the income, expenses and losses arising during implementation of innovative activity at key stages of its realization are provided.

Specification of the existing concept of tax accounting in commercial banks of the Russian Federation which, supplementing concept of tax accounting is given, defines concept of system of tax accounting, and also synchronously reflects essence, an orientation, a role and a place of tax accounting in the general system of the account; the purposes, tasks, functions and the principles of conducting tax accounting in the credit organization allowing to draw a conclusion on his independence and independence of system of accounting are specified and formulated. Tax accounting is formed on a joint of systems of accounting and the taxation (it is schematically displayed in fig. 5).
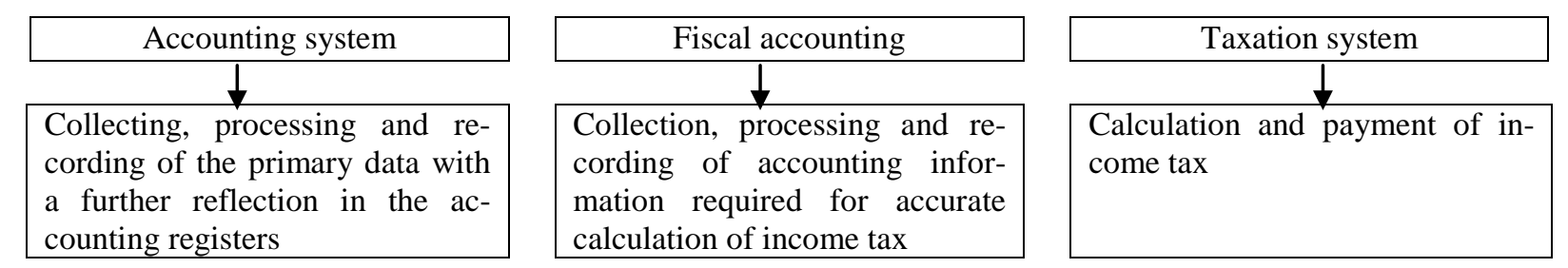

Fig. 5. A place of tax accounting in system of interactions of accounting and taxation

The tax accounting formed on a joint of contradictions of systems of accounting and the taxation it serves as an intermediate link between the considered systems where occur data collection and processing, necessary for the correct calculation of tax obligations. Thus the optimum model of coexistence of systems of accounting and tax accounting can be reached after integration and harmonization of objects of the account and the taxation.

The major factors of emergence of conflict situations between systems of accounting and 
tax accounting in work of commercial bank caused by absence between them a registration sheaf and interaction of two institutes of the country are revealed and classified: The Ministries of Finance of the Russian Federation and the Central bank Russian Federation connected with development of methodological and regulatory base of the accounting of tax requirements and obligations of the credit organization [3].

During scientific research the sites of conducting tax accounting in the credit organization allowing to reflect in due time the operations connected with recognition of expenses are considered and systematized (on deposit operations, advertizing, voluntary and obligatory insurance of employees and property of bank, the maintenance of the bank equipment and stock, etc.) and the income (which is subject to payment on the basis of a judgment, received when crediting clients and staff of bank, etc.); are developed the new list of registers of tax accounting for the credit organizations and a technique of their filling, allowing taking into account features of operations in commercial bank to make calculation of taxable base for income tax and to reveal divergences with accounting [19].

Officially tax accounting in a banking system was created after adoption of the 25th chapter of the Tax Code of the Russian Federation. After the adoption of this statutory act before the credit organizations there was a question: how to organize conducting tax accounting with what to use the methodological principles and, the main thing as in practice to construct system of "registers of tax accounting" which would meet the requirements of the legislation, without complicating thus work of registration divisions of the credit organizations.

For the solution of this problem in the credit organizations it is offered to divide tax accounting of the income, expenses and property of bank into 3 large sites proceeding from their specifics and the importance. Each site includ esseparate segments of the account (fig. 6).

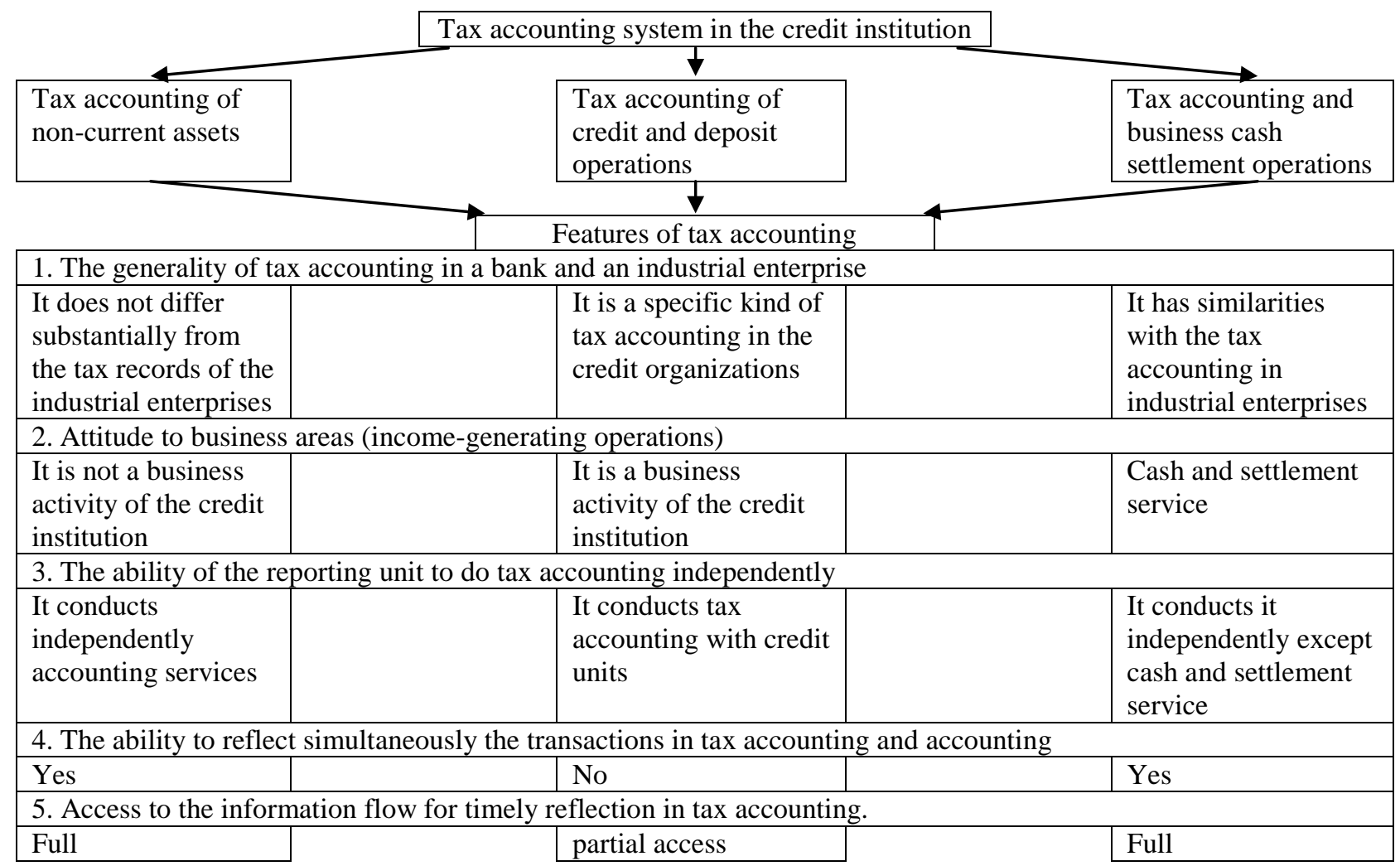

Fig. 6. System of construction and conducting tax accounting in the credit organization

The main directions of improvement of tax accounting in the credit organization allowing to establish interrelation of accounting and tax accounting on the basis of their integration and to define need of development of the joint analytical account, unification of registration forms, modification of organizational structure of bank in the conditions of automation of conducting tax accounting are revealed.

Ways of improvement of system of tax accounting by means of modern software products are planned: the main stages and the directions of automation of business process "Tax accounting" are defined and the algorithm of automation of the registers of tax accounting developed during sci- 
entific research for the purpose of decrease in material and labor inputs on its maintaining, elimination of information gaps, minimization of tax risks and increase of controllability of this process is offered.

It is expedient to carry out automation of business process of tax accounting in four stages on the following algorithm:

1. Development of technical requirements to the software product in which the subsystem "Tax accounting" will be created. In requirements it is necessary to work the following provisions: on the basis of what software products this subsystem will be developed; by forces of the credit organization or specialized consulting - engineering firm, etc. Before development of any technical and other requirements connected with automation of tax accounting it is necessary to make optimization business - processes and the organizational structure of bank connected with conducting tax accounting.

2. Definition of a framework of functionality of the introduced subsystem, i.e. what functions and operations will be automated in tax accounting of the credit organization. At this stage it is necessary to develop functional requirements to the introduced subsystem "Tax accounting".

3. Construction and introduction of a subsystem "Tax accounting" with a simultaneous optimization business - processes and organizational structure in the credit organization. The subsystem "Tax accounting" is intended for optimization of collecting, processing and storage of information necessary for drawing up the declaration on income tax. The scheme of consecutive work with system for receiving result looks as follows.

4. At the final stage the subsystem "Tax accounting" has to make automatically not only a choice of values from total fields of the created registers of tax accounting, but also their division according to the classification of the income and expenses stated in the 25th chapter of the Tax Code of the Russian Federation (the realization, extra realization which aren't considered) to perform calculation of taxable base and the sum of income tax. The declaration on income tax in the form approved by FTS of the Russian Federation has to be the final electronic document of a subsystem.

Transformation of the national reporting according to the international standards and standards of other countries

The content of national concepts of basic elements of financial statements regarding their compliance of IFRS for full information support of activity of foreign investors is theoretically specified; ways of improvement of Russian accounting standards and the reporting on the basis of creation of four-level standard and legal base [25] are developed.

The branch features for the enterprises of an oil and gas complex (further oil and gas company) maintaining the analytical account and drawing up the reporting caused by transition of the enterprises of oil products supply, oil processing and production to IFRS are revealed.

For the purpose of consolidation of data about maternal and subsidiaries the forms of financial statements providing structuring the report on a financial position (balance) and the profit and loss report on the basis of introduction of amendments and specifications in the scheme of the movement of information streams on accounting primary documents and the reporting in oil and gas company regarding separate reflection of registration data about maternal and subsidiaries, the accounting of expenses on investigation of oil [25] are developed.

The methodology of transformation of financial statements according to requirements of IFRS based on definition of the purpose and problems of transformation, the general strategy of an assessment of the account, development of methods of the analysis of the applied accounting and tax policy, updating of accounts, etc. is offered; the procedures including transfer of data from the ledger in transformational tables, drawing up trial transformational balance and other forms of the reporting, carrying out the correcting records in forms of financial statements, transformation of financial reports taking into account a difference in exchange rates for date of calculations, etc. [26; 27] are defined.

Are developed components of the analytical account, analysis of financial and economic activity, scenarios of future administrative decisions necessary for creation of the branch software product for an oil and gas complex and the providing conducting accounting, management and tax accounting, drawing up, transformation of the reporting taking into account branch specifics of OGC [37].

The orientation and extent of influence of processes on transition to IFRS of economic entities of the concrete region to the level of its competitiveness is revealed.

Strategy of transition to drawing up financial statements for the principles of the international standards by means of allocation of stages and formation of complex system of such transition is developed. 
The analysis of the key provisions of accounting policies corresponding to the principles of IFRS along with the admissible alternative options regulated in the Russian Provisions of Accounting is carried out.

The mechanism of transition to the international system of financial statements representing infrastructure for realization of complex system of introduction of IFRS is created.

Being guided by the theory and practice of the account, need of use of the integrated registration system of the foreign trade activity is proved; information model of registration system of the foreign trade activity is allocated, set of the principles of construction is offered and the model which is based on use of registers of management accounting as the domestic account which is most adapted for practice and rules of IFRS [30] is developed.

The scheme of the organization of the accounting of the foreign trade operations on the basis of the stage-by-stage approach considering features of state regulation of the foreign trade activity, the economic maintenance of two groups of operations is offered: foreign trade in goods, and foreign trade in services; and within stage-bystage approach the directions of adaptation of the accounting of the assets, obligations, income and expenses which are result of the foreign trade operations to provisions of IFRS are presented.

Stages of modeling of management accounting of the foreign trade activity on the basis of process approach are systematized and opened; the directions of use of provisions of IFRS in management accounting of the foreign trade activity are offered and proved.

The optimum system of management accounting of the foreign trade activity can be presented in the form of the following scheme (fig. 7).

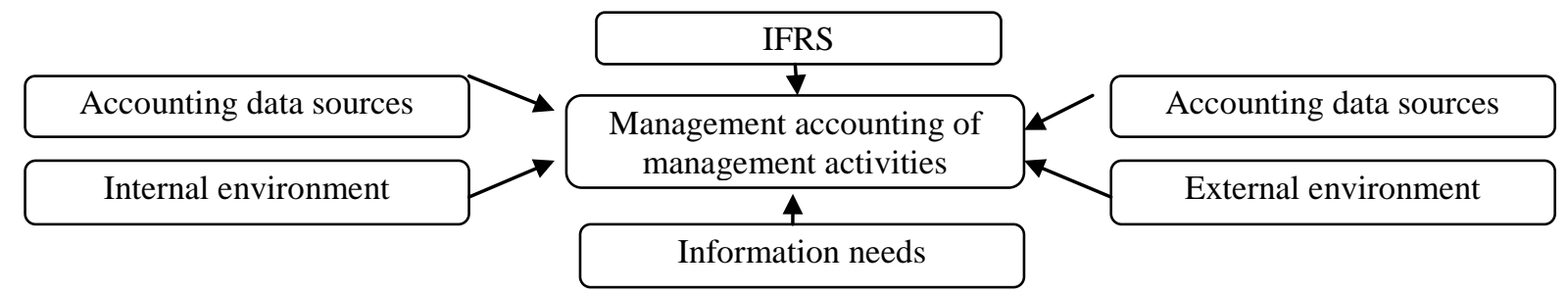

Fig. 7. The system of management accounting of the foreign trade activity based on the principles of IFRS

Information on the foreign trade activity for the administrative purposes arrives not only from registration and extra registration data, but also from the external and internal environment. The system of management accounting of the foreign trade activity is under construction by the principles of IFRS and in case of a need can be base for preparation of the reporting under IFRS. Thus the international standards are used as a platform, and in case of their restriction can be replaced with national standards.

This approach is connected with that use of this or that standard for the purposes of management accounting by the foreign trade activity is defined by specifics of activity of the companies and structure of economic operations.

It is expedient to use the financial reports recommended to IFRS and in management accounting of the foreign trade activity. Implementation of requirements of IFRS (IAS) 1 "Submission of financial statements" provides comparability both own reports for the different periods, and the reporting of the different companies. At the same time for management accounting of the foreign trade activity also other reports which aren't regulated by the standard $[9 ; 38 ; 39]$ are required.
2. Development of the theory and history of development of methodology and organization of the economic analysis of financial and economic activity

Concept of a technique of the analysis of economic potential of an economic entity

The content of concept of economic potential of an economic entity as integrated characteristic of efficiency of its activity and prospects of development which basis is made by system of retrospective and perspective indicators and criteria of their assessment [10] is specified.

The new classification signs of structuring economic potential and its components in a section of types and character of resources, the directions of the analysis allowing to carry out the complex analysis of efficiency of activity and prospects of development of an economic entity with sufficient specification of factors of influence and interrelations between them are formulated.

Own structure of the economic potential (fig. 8) is created. As the main classification sign the resources which are the cornerstone of a component act, technological, labor, financial and market potentials are as a result allocated [17]. 


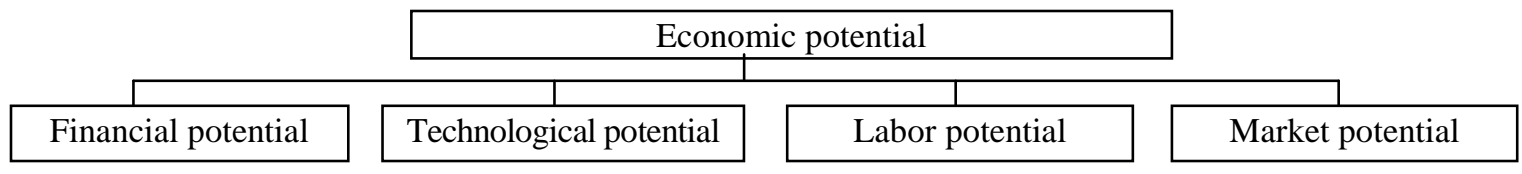

Fig. 8. Structure of economic potential

Within this structure four main components of potential are created. Financial potential includes financial resources of the enterprise. Technological potential united in itself material and resource aspects of activity. Labor potential assumes consideration of all questions connected with the personnel of the organization, quantity and quality of work, motivation. Marketing activity, enterprise abilities, market conditions are the cornerstone of market potential. Level of innovative development of the enterprise isn't allocated in a separate component. Its studying is carried out through an assessment and the analysis of conditions of innovative development which contain in all four components. Application of this approach is proved by that innovative activity is closely connected with all components of economic potential and can't exist separately.
Strengthening of innovative activity becomes possible at a sufficient level of development of each component, to be exact - in the presence of qualitative conditions of innovative development.

Each of the offered components, in turn, is an element of the highest level in the local hierarchical structure. Thus, in the analysis of components of potential it is expedient to use the same approaches and methods, as in the analysis of economic potential. For each component the hierarchical structure into which some blocks of indicators enter is created. Technological potential includes estimates of a level of development of the equipment, production infrastructure, productions (fig. 9). The relation to production process is the cornerstone of classification (direct and auxiliary, active and passive).

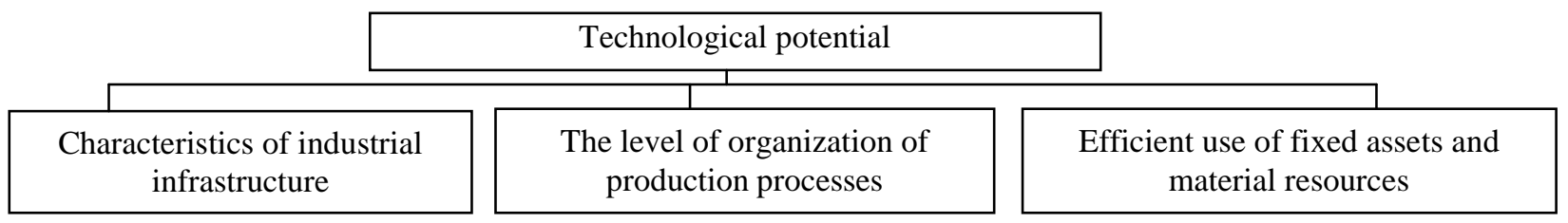

Fig. 9. Structure of technological potential

The main sign for structuring financial potential are various aspects of financial side of activity of the subject. In addition within the analysis of financial potential investment appeal and existence of sources of means for financing of innovative activity are estimated. The structure is presented in fig. 10.

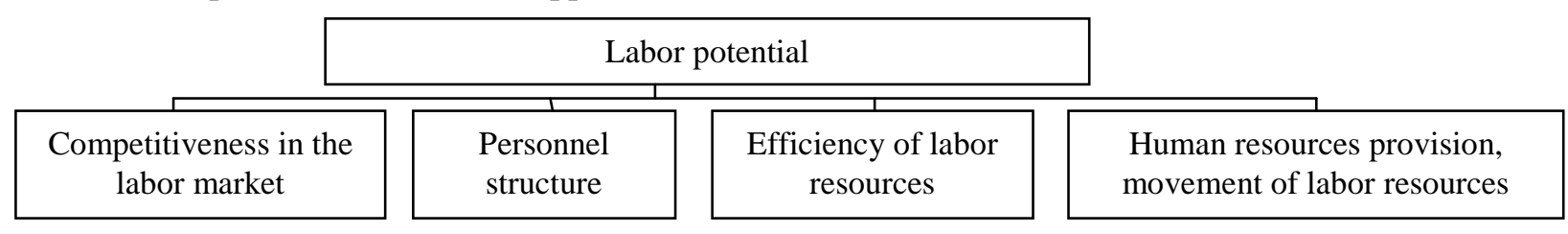

Fig. 10. Structure of financial potential

The analysis of labor potential assumes a versatile assessment of a manpower, quantities and qualities of work which can be received.
Within research of this component also competitiveness of the enterprise in labor market (fig. 11) is analyzed.

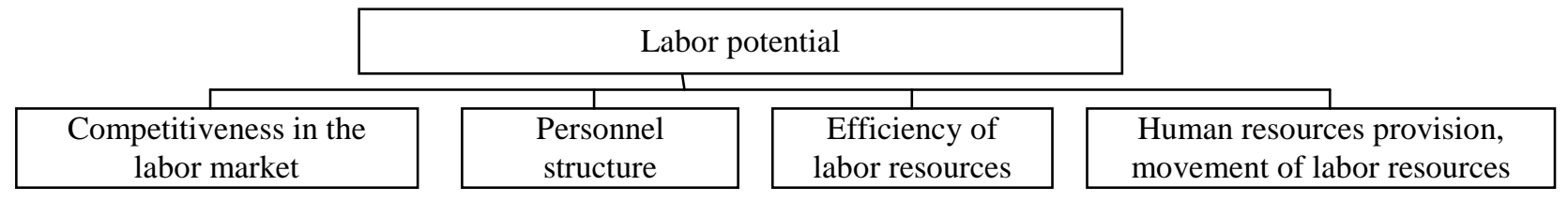

Fig. 11. Structure of labor potential

The fourth component of economic potential is market potential. In the analysis of this component are considered as own efforts, oppor- tunities and abilities of an economic entity, and the general economic environment, capacity of the market at which the enterprise (fig. 12) works. 


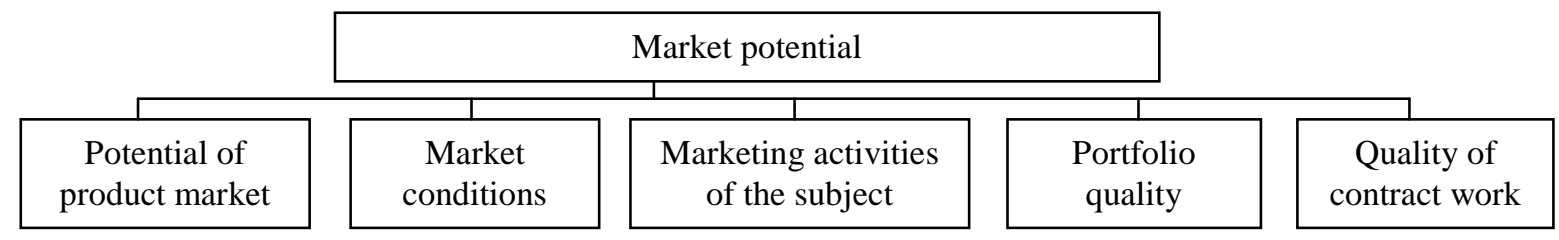

Fig. 12. Structure of market potential

The features of economic potential and its components which expanded possibilities of deepening of the analysis of their influence on efficiency of activity and prospect of stable development of an economic entity are revealed: 1) decrease in economic potential eventually in the absence of purposeful influences; 2) balanced growth of economic potential; 3) relativity of economic potential and its components.

The technique of the analysis of influence of economic potential and its components on the flowing and expected results of activity of an economic entity which assumes passing of several stages is developed:

1. The volume of basic data is defined: the available indicators, the periods, qualitative information, judgments and estimates of experts which can be formalized.

2. Distribution of indicators on belonging to this or that component of potential according to their essence, nature of influence is made.

3. The hierarchical structure of indicators is formed.

4. For each indicator criteria of an assessment of their quality and efficiency are defined. Key aspect of the analysis of economic potential is definition of system of criteria of an assessment of indicators. For each component of economic potential it is possible to define the sources of formation of criteria of an assessment. Sources can be divided on internal and external. Strategic objectives of the company, requirement of the enterprise according to implementation of the production program belong to the internal. The state and international standards belong to the external indicators of the comparable enterprises and leaders of branch; requirements of the credit organizations, investment funds and rating agencies; demographic statistics, etc.

5. On the basis of the established criteria rationing (3) all indicators used in calculations is made. The structure consisting of rated private criteria is as a result formed.

$$
D_{i, \text { norm }}=\left(\frac{D_{i}}{D_{\max }}\right),
$$

where $\mathrm{Di}$, norm - rated value of private criterion [0; 1]; Di - the actual value of an indicator; Dmax - the maximum (best) value of an indicator.
6. The coefficient is appropriated to each indicator used at aggregation in a section of components, similarly - the weight coefficient when forming global criterion of efficiency is appropriated to each component of potential - economic potential. Methods of expert estimates, statistical methods can be applied to ranging on a significance value.

7. On the basis of the received values aggregation of private criteria in a section of components of economic potential is made. Aggregation can be carried out by one of two ways: additive or multiplicative. The choice of a way of aggregation depends on nature of interrelation of the indicators forming each component of economic potential. From the practical point of view, the difference between ways of aggregation consists in number of factors which influence the size of an integrated indicator. At calculation by a multiplicative method two factors have impact on total result: the size of values of the displaced indicators, dispersion of values of indicators concerning an average. It means that the enterprise won't possess very high cumulative potential if there is at least one indicator having extremely low value. When using additive models at aggregation of indicators for the analysis of potential influence of one factor - the size of indicators is reflected. The dispersion of values of indicators of rather average value isn't taken into account. Justification of a choice of a way of aggregation is of great importance in the analysis of economic potential as the received results directly depend on it.

8. The estimates of components of potential received as a result of the analysis are displaced in the global indicator of efficiency characterizing the economic potential of an economic entity. Studying of the specified indicator in dynamics allows to use it for monitoring of efficiency of activity of the enterprise. It should be noted that the received system of estimates of components of potential, even without aggregation to a uniform global indicator, can be used for the analysis of activity of the subject.

The approaches to an integrated assessment of economic potential of an economic entity allowing to control prospects of its stable development are found. 
For an integrated assessment of economic potential the model constructed on the basis of the developed technique is offered. The indexes created from the indicators aggregated as appropriate are its cornerstone. Thus each indicator is built in model not in pure form, and in the form of the attitude towards criterion. Indexes by means of aggregation connect in analytical estimates of components of potential, and the specified estimates form the highest element of hierarchical system - the economic potential.

Indexes of technological potential: IEq an index of a level of development of the production equipment; $\mathrm{IPr}$ - an index of development of productions; Iinf - an index of development of infrastructure.

Indexes of labor potential: Is - an index of quality of structure of the personnel of the organization; Ief - an index of efficiency of use of work; Ic - an index of competitiveness of the enterprise in labor market; Io - an index of security with a manpower and the movements of shots.

Indexes of financial potential: Iliq - a liquidity index; Ieffie - an index of efficiency of use of financial resources; Iust - an index of financial stability and solvency; linv - an index of investment appeal.

Indexes of market potential: Igm - potential and an environment of the markets; Imark an index of efficiency of marketing activity of the enterprise; Icontract - an index of quality of contractual work; Iinv - an index of quality of a portfolio of orders.

For receiving an index one indicator is necessary at least. Value of indicators changes in the range from 0 to 1 . Consecutive aggregation at all levels of structure to the top hierarchical level gives the following restrictions for values of elements of model:

$$
P_{\text {max }}=P_{L \text { max }}=P_{T_{\text {max }}}=P_{M \text { max }}=P_{F \text { max }}=I_{\text {max }}=D_{\text {max }}=1
$$

It should be noted that the analysis of change of economic potential can be carried out for the solution of specific administrative objectives. It is in addition necessary to note that at the disposal of the analyst there can be a limited volume of data on object of research. It can be caused as the subjective reasons (limitation of access to information), and the objective reasons (lack of appropriate collecting and systematization of information at the analyzed enterprise).

Methodical bases of the strategic analysis of the external (business) environment of the agricultural organizations.

The technique of a complex assessment of tendencies of the external near business environment of the agricultural organizations considering set of factors of formation of their competitiveness at the level of the region, branches, the municipal area, allowing to form most reasonably strategy of a sustainable development of agricultural production in the conditions of the competition is developed.

The analysis of the external near business environment it is offered it is carried out on the following stages: - an assessment of a rating of Perm region on the main socio-economic indexes among subjects of the Volga Federal District, including for more profound analysis: an assessment of a state and the main tendencies of development of branch "Agriculture, hunting and forestry" in the territory of Perm region; - an assessment of a rating of the certain municipal area among subjects of Perm region on the main economic indicators characterizing intensity and efficiency of activity of the agricultural organizations; - an assessment of a rating of the agricultural organization for indicators of a financial state among subjects of the municipal area, and also rather main competitors - the agricultural organizations of Perm region and Volga federal district.

Division of powers and responsibility on the strategic centers of financial responsibility is offered: the entering expenses, expenses (the expired expenses), sales, the income, investment (innovations), arrived (strategy); set of objects of the strategic account and control is structured, the system of quantitative indices for an assessment of the main tendencies of objects of management across the Central federal district allowing to approach more structurally a question of development of the system of the strategic administrative reporting is developed.

Generalizing the saved-up experience and considering specifics of modern control systems and strategic management accounting, we consider that the center of financial responsibility (the center of responsibility) is the segment of financial structure of the organization focused on achievement of strategic objectives and tasks, which is flexibly reacting to changes of strategy of the organization and environment, having powers to control and coordinate business processes during realization of strategy of the enterprise, bearing responsibility for the level of productivity and efficiency of under control business processes. Proceeding from it, it is possible to understand hierarchical system of the strategic centers of financial responsibility as financial structure of the organization, logically connected among themselves, with the main business processes, strategic objectives and tasks. As a part of financial structure of the organization allocation of the following 
centers of financial responsibility is offered: the entering expenses, expenses (the expired expenses), sales, the income, investment (innovations), arrived (strategy). Decomposition of financial structure of the organization for the centers of financial responsibility allows to approach a question of development of the system of the strategic administrative reporting more structurally. The quantitative indices of an assessment of the main tendencies of objects of management defining contents of the strategic administrative reporting, providing its addressing, an exception of duplication of administrative functions (tab. 4) are developed for the solution of this problem in Central federal district coal mine.

Key indicators of an assessment of efficiency of activity of the agricultural organization in a section of the centers of financial responsibility

\begin{tabular}{|c|c|c|}
\hline $\begin{array}{l}\text { A homogeneous } \\
\text { group of financial } \\
\text { responsibility centers }\end{array}$ & $\begin{array}{c}\text { Financial } \\
\text { Responsibility } \\
\text { Center }\end{array}$ & Key figures \\
\hline \multirow[t]{2}{*}{ Incoming Cost Centers } & $\begin{array}{l}\text { Center of non- } \\
\text { current assets }\end{array}$ & $\begin{array}{l}\text { The average annual value of fixed assets, capital productivity, the tech- } \\
\text { nical level of the shelf, the update period }\end{array}$ \\
\hline & $\begin{array}{l}\text { Center of material } \\
\text { costs }\end{array}$ & $\begin{array}{l}\text { The cost of inventories, cost of maintenance of storage facilities, the } \\
\text { size of shortages and losses }\end{array}$ \\
\hline \multirow[t]{2}{*}{$\begin{array}{l}\text { Spending centers } \\
\text { (of expired costs) }\end{array}$} & The cost center & $\begin{array}{l}\text { The duration of the production cycle, the volume of production, the } \\
\text { rhythm of production costs, product quality, the percentage of marriage, } \\
\text { the level of waste production profitability }\end{array}$ \\
\hline & $\begin{array}{l}\text { Centre of } \\
\text { administrative } \\
\text { expenses }\end{array}$ & The level of administrative expenses for 1 rbl. volume of production \\
\hline \multirow[t]{3}{*}{ Sales centers } & $\begin{array}{l}\text { Center for the } \\
\text { foreign market }\end{array}$ & \multirow{2}{*}{$\begin{array}{l}\text { Terms of shipment of products, order fulfillment, after sales service } \\
\text { efficiency, structure of sales, return on sales, warranty repair and } \\
\text { maintenance costs, the amount (volume) of complaints and returns, }\end{array}$} \\
\hline & $\begin{array}{l}\text { The center of the } \\
\text { internal market }\end{array}$ & \\
\hline & Clearance Center & Maturities of receivables overdue, doubtful trade receivables \\
\hline \multirow[t]{3}{*}{ Revenue centers } & $\begin{array}{l}\text { Center of sales } \\
\text { strategy }\end{array}$ & $\begin{array}{l}\text { The number of new customers, additional sales volume, the volume of } \\
\text { new and upgraded products, its share in the total sales volume, the level } \\
\text { of competitiveness of the main products }\end{array}$ \\
\hline & Pricing Center & $\begin{array}{l}\text { Price ratio to the average level of the industry, the region, the market, } \\
\text { with its main competitors the price level, the share of revenue and profit } \\
\text { margin in the price }\end{array}$ \\
\hline & Loan Center & $\begin{array}{l}\text { The size of discounts for } 1 \text { rbl. revenue, sales volume growth in volume } \\
\text { and value terms, the level of customer satisfaction }\end{array}$ \\
\hline \multirow[t]{4}{*}{ Investment Centers } & $\begin{array}{l}\text { Center of cash } \\
\text { flows }\end{array}$ & $\begin{array}{l}\text { The growth of the volume of cash flows, discounted cash-flow rate, } \\
\text { liquidity ratios, solvency, financial independence and sustainability }\end{array}$ \\
\hline & $\begin{array}{l}\text { The center } \\
\text { financial } \\
\text { investments }\end{array}$ & $\begin{array}{l}\text { Return on invested capital, the process increments the market value of } \\
\text { the enterprise. }\end{array}$ \\
\hline & $\begin{array}{l}\text { Center of product } \\
\text { innovation }\end{array}$ & $\begin{array}{l}\text { The period of new product development, payback period, the share of } \\
\text { new products in the total sales volume }\end{array}$ \\
\hline & $\begin{array}{l}\text { Center of } \\
\text { management } \\
\text { innovations }\end{array}$ & $\begin{array}{l}\text { Term of preparation of management reporting, the quality of accounting } \\
\text { information, the quality of the communications system, the level of } \\
\text { efficiency of management decision-making }\end{array}$ \\
\hline \multirow[t]{3}{*}{$\begin{array}{l}\text { Profit Centers } \\
\text { (strategy) }\end{array}$} & $\begin{array}{l}\text { Strategic Planning } \\
\text { Center }\end{array}$ & $\begin{array}{l}\text { Gross, operating and net profit; return on equity, production, sales, } \\
\text { economic value added, liquidity ratios, solvency, financial independ- } \\
\text { ence and sustainability }\end{array}$ \\
\hline & $\begin{array}{ll}\text { Center for } \\
\text { Strategic } \\
\text { Controlling }\end{array}$ & $\begin{array}{l}\text { The level of competitiveness of the main products, the dynamics of } \\
\text { significant trends of macro and micro environment, the impact of fac- } \\
\text { tors on the results of operations }\end{array}$ \\
\hline & Motivation Center & $\begin{array}{l}\text { The average number of staff, the average age of the personnel, the level } \\
\text { of job satisfaction of staff, level of education and qualification, the } \\
\text { number of innovation proposals by } 1 \text { employee share incentive pay- } \\
\text { ments to payroll, turnover rate, the rate of growth of labor productivity, } \\
\text { reduction of losses }\end{array}$ \\
\hline
\end{tabular}


Decomposition of financial structure of the organization to the centers of financial responsibility allows to approach more structurally a question of development of the system of the strategic administrative reporting as bases for adoption of strategic administrative decisions.

3. Development of the theory and history of development of methodology of audit Development of methodology and the organization of audit in commercial banks

The theoretical and methodological content of the concept "tax audit" allocating it from structure of audit of financial (accounting) statements, the services accompanying audit and other services connected with auditor activity in an independent type of auditor activity [23] is specified.

In spite of the fact that the concept "tax audit" (in various variations) is rather often used in special literature, it still didn't find the only right and theoretically reasonable interpretation. The existing domestic legislation and the International standards of audit also don't open the concept "tax audit".

Taking into account the system analysis of the legislation and scientific works on the matter the concept "tax audit" as which it is necessary to understand the type of auditor activities for independent verification of the tax reporting of the audited face for expression of opinion on reliability of such reporting urged to give to the audited face help performed by the constitutional obligation for payment of lawfully established taxes in full accordance with requirements of the existing tax law is defined.

The theoretical and methodological content of the concept "organization of tax audit" which is earlier not opened in special literature, reflecting intrinsic properties of the organization as process is specified. On the basis of this concept the author's concept of the organization of tax audit in commercial banks assuming active participation of the management of the auditor company in the organization of the following processes is developed: preparation for tax audit and making decision on its carrying out in bank, checks in essence, quality control and leading of results.

The concept "organization of tax audit" isn't opened in special literature in spite of the fact that authors actively use it in the works, many of which are devoted to directly this problem.

On the basis of the analysis of approaches of various researchers to the organization of tax audit, and also definition of the concept "organization", the author specified the theoretical and methodological content of the concept "organization of tax audit" as which it is necessary to un- derstand activities of the management of audit organization for management of actions of her employees, maintenance of information exchange between subjects of tax audit and to providing all course of tax audit on each of its stages: preparation and making decision on carrying out tax audit, check performance in essence, quality control of carrying out tax audit and leading of its results, for the purpose of rendering to the audited face of services in tax audit of appropriate quality.

Methodical provisions according to reliability of system of internal control of commercial bank regarding the organization of the taxation which is carried out in six directions are developed: an assessment of style of the management, an assessment of organizational structure of bank, an assessment of personnel policy and distribution of powers, an assessment of quality of internal regulatory base, an assessment of quality of work of divisions of bank and an assessment of reliability of the automated systems of data processing used at calculation of taxes and drawing up the tax reporting [22].

For high-quality planning of the inspection in essence which is carried out within tax audit in bank, the auditor needs to study his system of internal control (further - SIC) regarding the organization of the taxation. The assessment of risk of control devices has to become result of such analysis.

When developing this technique we recede from concept of system of the internal control offered by Federal rules (standards) of auditor activity (further - FRSA), using other approach and terminology during the studying of SIC of bank and an assessment of its influence on reliability of information reflected in the tax reporting. We allocate six directions of studying of SIC of bank.

Each of the directions is connected with studying of the relevant party of SVK of bank having direct impact on reliability of the tax reporting. The brief of the auditor allowing on the basis of ball to estimate reliability of SVK of bank regarding the organization of the taxation and to calculate the size of risk of control devices is developed.

Methodical provisions on carrying out in commercial banks of audit of accounting policies for the taxation, and also audit of the income tax and the connected operations including audit of the tax reporting under the property tax, transport and land taxes [24] are developed.

[5; 6]

Theory and practice forensic accounting

The concept of economic examination which considers character and procedural features of its carrying out is specified, and also limits of 
powers of the expert-economist taking into account his role and legal status are defined.

Uniform classification of economic examinations which unlike the existing classifications considers established practices of purpose of economic examinations in trial is created and provides differentiation of a subject of expert research.

The order of formation of a technique and sequence of carrying out forensic accounting considering unlike the approaches considered in special literature, an essence of an economic offense, use of special methods and feature of drawing up the conclusion of the expert-accountant are specified.

The integrated approach to standardization of forensic accounting which assumes establishment of certain uniform organizational and methodical requirements to experts and to a procedure of their activity is developed.

The principles of its carrying out and campaigns to an assessment of qualification of the expert-accountant which weren't considered in special literature earlier are developed taking into account procedural nature of forensic accounting.

Situation on carrying out judicial and forensic accounting which considers the modern procedural legislation, uniform approaches to carrying out is developed.

Concept of development of system of regulation of auditor activity

The theoretical and methodical provisions making the concept of development of system of regulation of the auditor activity corresponding to modern market conditions on the basis of the analysis of its historical development and the acting practice are developed. The most essential results consist in the following $[1 ; 2 ; 4 ; 7 ; 11 ; 12$; 13; 14]:

- the theoretical and methodological content of the concept "system of regulation of auditor activity in the Russian Federation" for audit acting as alternative to the content of the concept "system of standard and legal regulation of auditor activity" of economical legal relations and differing from it in a multilevel hierarchical structure and allocation of elements of the state, professional, public and intra firm regulation, and also considering need of rapprochement of domestic auditor activity with the international standards is specified;

- on the basis of the complex analysis of the functions which are carried out at all levels of system of regulation of auditor activity (state, professional, public, intra firm), the expressed discrepancies limiting adequate functioning of the considered system are revealed. The functions which are carried out by elements of system of regulation of auditor activity in the market of auditor services that will allow to satisfy new needs of subjects of the auditor market based on selfregulation are redistributed and added;

- the key directions of development of the basic principles of auditor activity (obligatory audit, auditor secret, independence of auditors) in the course of transition from forms and methods of mainly state regulation of subjects of the auditor market to their self-regulation are revealed;

- key tendencies of development of relationship of subjects in the market of auditor services which basis make the progressing dynamics of application of the regulating norms, and also the high-quality change of character of the relations of participants of the auditor market generated by an intensification of use of system of the regulating norms are formulated;

- need of systematization of the legislation regulating auditor activity is proved. The new regulating act - the Auditor code within which its structure and basic provisions meeting the modern requirements imposed to system of regulation of auditor activity are developed is theoretically reasonable and offered; the code place in hierarchy of the regulating norms is defined. It in total causes need of development of a subsystem of state regulation of auditor activity;

- approach to development of organizational and methodical tools of development of subsystems of non-state regulation of auditor activity (professional, public, intra firm) within its modern concept is formulated;

- the contents "audit" and "auditor activity" (thus the understanding of audit united legislatively as the isolated process and a type of business activity is shared) is specified, the formulation of the concept "standard of audit" is simplified and the emphasis is placed on its role in ensuring quality of audit; definition of quality of audit taking into account provisions of the economic theory is given; definitions of the terms "audit level of quality", "criterion of quality of audit", "system of regulation of quality of audit", "quality management system of audit" are formulated;

- it is offered to include in the scheme of creation of the theory of audit along with the available elements the fundamental principles of audit; the quantity, names and definitions of concepts are specified; the lacking principles of responsibility and a postulate concerning auditor proofs are formulated; the through interrelation between the offered principles, concepts, postu- 
lates and standards of audit is opened (international and national); offers on group of federal rules (standards) of auditor activity with use of process approach are made;

- proceeding from unity of an accounting and auditor profession, the model of the qualitative focused system of regulation of auditor activity, consisting of standard and legal, professional and public and internal subsystems is proved; taking into account this division offers on formation of system of measures of responsibility of auditors and auditor firms are made;

- as a result of harmonization of the principles and requirements imposed to formation of systems of quality management by standards of the International organization for standards (ISO), the International organization of accountants, the reporting state standard specifications and rules (standards) of auditor activity process approach to regulation of quality of audit is reasonable and elements of quality management system of audit for reflection in the corresponding federal rule (standard) are formulated;

- recommendations about improvement and unification of techniques of quality control of audit from the licensing and the accredited professional auditor associations are developed; ways of impact on quality of auditor services from selfregulating professional communities are defined, offers concerning conditions of emergence and termination of membership in professional auditor associations are for this purpose formulated;

- possibilities of influence of clients of auditor firms on quality of audit are opened: by means of creation of auditor committees and the organization of open competitions on the right of the conclusion of contracts for carrying out audit inspections; recommendations about establishment of the competitive conditions allowing to eliminate applicants the audit organizations obviously not capable to provide due quality of services are made; approaches to regulation of quality of audit are offered by a host; methods of obtaining information on satisfaction of consumers with quality of the carried-out inspections are defined;

- with use of process approach to regulation of quality of audit classification of intra firm rules (standards) of auditor activity and objects of standardization is developed, the circle of the tasks solved by means of computer methods of audit is defined and systematized including the directions of creation of tools of implementation of internal regulation of quality of audit are revealed;
- the complex of actions is developed: on ensuring compliance by the personnel and the management of auditor firm of the fundamental principles of audit; on formation and optimization of use of personnel potential (the professional passport of the employee of audit organization is for this purpose created); approximate qualification requirements to various categories of employees of department of audit are offered;

- the technique of an assessment of the potential client of audit organization is created, offers on selection and preservation of customers are formulated;

- are developed: algorithm of carrying out monitoring of intra firm system of regulation of quality of audit, a technique of an assessment of its state and definition of the directions of improvement on the basis of realization of an integrated approach taking into account requirements of the ISO standards and audit.

\section{References}

1. Gorodilov M.A. Razvitie sistemy normativno-pravovogo regulirovaniia auditorskoi deiatel'nosti $v$ Rossiiskoi Federatsii [Developing the system of auditing activities legal regulation in the Russian Federation]. Moscow, Finansy i statistika Publ., 2009. 480 p.

2. Molodye uchenye o sovremennom sostoianii kontrol'no-uchetnoi i analiticheskoi deiatel'nosti $v$ rynochnoi ekonomike [Young scientists about the current state of control-accounting and analytical activities in market economy: collected scientific articles]. Ed. by T.G. Sheshukova. Perm, Perm State University Publ., 2014. Iss. 4. 172 p.

3. Nikitina E.B. Neobkhodimost' i puti povysheniia statusa regionalnykh bankov $\mathrm{v}$ rossiiskoi bankovskoi sisteme [The necessity and ways for improving the status of regional banks in the Russian banking system]. Vestnik Permskogo universiteta. Ser.: Ekonomika [Perm University Herald. Economy], 2012, no. 4 (15), pp. 75-80.

4. Pankova S.V. Metodologiia i praktika regulirovaniia kachestva audita [Methodology and practice of auditing quality regulation]. Orenburg, Orenburgskoe knizhnoe izdatel'stvo Publ., 2001. 304 p.

5. Pashchenko T.V. Razvitie teoreticheskikh osnov sudebno-bukhgalterskoi ekspertizy: opredelenie kvalifikatsii eksperta i eticheskie printsipy [Development of theoretical bases of judicial and accounting examination: assessment of the expert qualifications and ethical principles]. Vestnik Permskogo universiteta. Ser.: Ekonomika [Perm University Herald. Economy], 2014, no. 3, pp. 82-89.

6. Pashhenko T.V., Sheshukova T.G. Razvitie teorii i praktiki bukhgalterskoi ekspertizy [Forensic accounting theory and practice development]. Perm, Perm State University Publ., 2010. 170 p. 
7. Posokhina A.V. O problemakh auditorskoi deiatel'nosti $\mathrm{V}$ Rossii cherez prizmu soputstvuiushchikh uslug [On the problems of auditing activities in Russia through the prism of agreed-upon procedures]. Vestnik Permskogo universiteta. Ser.: Ekonomika [Perm University Herald. Economy], 2014, no. 3, pp. 90-98.

8. Razvitie uchetno-analiticheskoi i kontrolnoi sistemy $v$ usloviiakh globalizatsii ekonomicheskikh processov [Development of the accounting-analytical and control system under the conditions of economic processes globalization: collected scientific articles]. Ed. by T.G. Sheshukova. Perm, Perm State University Publ., 2013. Iss. 4. 132 p.

9. Rybalko O.A. Organizatsiia ucheta vneshnetorgovoi deiatel'nosti $v$ usloviiakh adaptatsii $k$ MSFO [Organization of foreign trade activity accounting under the conditions of adaptation to IFRS]. Perm, Perm State Agricultural Academy Publ., 2011. 171 p.

10. Sosnenko L.S. Analiz ekonomicheskogo potentsiala deistvuiushhego predpriiatiia [Analysis of economic capacity of the operating enterprise]. Moscow, ID Ekonomicheskaia literatura Publ., 2003. 209 p.

11. Sheshukova T.G., Beresneva A.V. Sovershenstvovanie primeneniia analiticheskikh procedur v auditorskoi proverke predpriyatiia [Improvement of analytical procedures application in audit inspection of an enterprise]. Perm, West-Ural Institute of Economics and Law Publ., 2014. 149 p.

12. Sheshukova T.G., Beresneva A.V. K poniatiiu analiticheskikh procedur $\mathrm{v}$ audite [About the analytical procedures concept in audit]. Auditor [Auditor], 2014, no. 8 (234), pp. 28-33.

13. Sheshukova T.G., Beresneva A.V. Primenenie statisticheskikh metodov $\mathrm{v}$ auditorskoi vyborke [Applying statistical methods to audit sampling]. Audit i finansovyi analiz [Audit and Financial Analysis], 2014, no. 2, pp. 173-178.

14. Sheshukova T.G., Beresneva A.V. Razvitie metodiki primeneniia analiticheskikh procedur na etape planirovaniia auditorskoi proverki [Development of the guidelines on applying analytical procedures at the audit planning stage]. Auditorskie vedomosti [Audit Journal], 2014, no. 10, pp. 45-60.

15. Sheshukova T.G., Vojtenko M.L. Razvitie sistemy upravlencheskogo ucheta (na materialakh predpriiatii nefteproduktoobespecheniia) [Development of management accounting system (on the data of petrochemicals supplying enterprises)]. Perm, Perm State University Publ., 2009. 217 p.

16. Sheshukova T.G., Ivannikov S.N. Sovershenstvovanie ucheta i kontrolia ispol'zovaniia osnovnykh sredstv [Improvement of analysis and controlling of fixed assets usage]. Perm, Perm State University Publ., 2007. 116 p.

17. Sheshukova T.G., Kolesen' E.V. Sovershenstvovanie metodiki analiza ekonomicheskogo potentsiala khoziaistvuiushchego sub'ekta [Improving technique of an economic entity potential analysis]. Perm, Perm State University Publ., 2013. 196 p.

18. Sheshukova T.G., Kotova K.Yu. Organizatsiia vnutrennego kontrolia $v$ kommercheskikh bankakh [Organization of internal control in commercial banks]. Perm, Perm State University Publ., 2004. $174 \mathrm{p}$.

19. Sheshukova T.G., Kustov P.I. Nalogovyi uchet $v$ kreditnykh organizatsiiakh (na primere naloga na pribyl') [Tax accounting in credit entities (on income tax data)]. Perm, Perm State University Publ., 2007. 223 p.

20. Sheshukova T.G., Mukhina E.R. Razvitie upravlencheskogo ucheta na predpriiatiiakh po proizvodstvu elektrotekhnicheskoi produktsii [Development of management accounting for electrical industry enterprises]. Perm, Perm National Research Polytechnic University Publ., 2015. 208 p.

21. Sheshukova T.G., Mukhina E.R. Analiz effektivnosti deistvuiushchei sistemy upravlencheskogo ucheta na predpriiatiiakh elektrotekhnicheskoi otrasli [Efficiency analysis of the current system of management accounting in enterprises of electrotechnical industry]. Upravlencheskii uchet [Management accounting], 2014, no. 3, pp. 65-74.

22. Sheshukova T.G., Orlov D.V. Razvitie metodologii i organizatsii nalogovogo audita $v$ kommercheskikh bankakh [Development of methodology and organization of tax audit in commercial banks]. Perm, Perm State University Publ., 2012. 283 p.

23. Sheshukova T.G., Orlov D.V. Nalogovyi audit kak samostoiatel'noe napravlenie auditorskoi deiatel'nosti [Tax audit as an independent type of audit activity]. Vestnik Permskogo universiteta. Ser.: Ekonomika [Perm University Herald. Economy], 2011, no. 1 , pp. 62-70.

24. Sheshukova T.G., Orlov D.V. Audit uchetnoi politiki dlia tselei nalogooblozheniia [Audit of accounting policy for tax assessment]. Ekonomicheskij analiz: teoriya i praktika [Economic analysis: theory and practice], 2010, no. 12, pp. 48-52.

25. Sheshukova T.G., Ponomareva S.V. Teoriia i praktika transformatsii Rossiiskoi finansovoi otchetnosti $v$ sootvetstvii s mezhdunarodnymi standartami [Theory and practice of Russian accounting transformation according to the international standards]. Perm, West-Ural Institute of Economics and Law Publ., 2006. 208 p.

26. Sheshukova T.G., Ponomareva S.V. Otsenka i transformaciia statey finansovykh aktivov i obiazatel'stv $\mathrm{v}$ format MSFO [Estimation and transformation of financial assets and liabilities items into the IFRS format]. Mezhdunarodnyi bukhgalterskii uchet [International Accounting], 2011, no. 28, pp. 2-12.

27. Sheshukova T.G., Ponomareva S.V. Adaptacionnaia metodika otsenki finansovykh instrumentov po spravedlivoi $\mathrm{i}$ amortizirovannoi stoimosti $\mathrm{v}$ sootvetstvii s trebovaniiami MSFO [Adaptive methods of assessment of financial instruments at fair and amortized cost in accordance with IFRS]. Vestnik Permskogo universiteta. Ser.: Ekonomika [Perm University Herald. Economy], 2011, no. 2, pp. 86-92.

28. Sheshukova T.G., Ponomareva S.V. Sposoby sostavleniia, primeneniia i transformatsii bukhgalterskogo balansa v mezhdunarodnoi i rossiiskoi 
uchetnoi praktike [Methods of compilation, application and transformation of balance sheet in international and Russian accounting practice]. Mezhdunarodnyi bukhgalterskii uchet [International Accounting], 2005, no. 9, pp. 3-10.

29. Sheshukova T.G., Razuvaeva K.V. Stanovlenie i napravleniia razvitiya bukhgalterskogo (biudzhetnogo) i nalogovogo ucheta $v$ gosudarstvennykh obrazovatelnykh uchrezhdeniiakh vysshego professional'nogo obrazovaniia [Formation and directions of development of business (budgetary) and tax accounting in state educational institutions of higher education]. Perm, Perm State University Publ., WestUral Institute of Economics and Law Publ., 2011. 127 p.

30. Sheshukova T.G. Rybalko O.A. Razvitie ucheta $i$ vnutrennego kontrolia vneshnetorgovoi deiatel'nosti predpriiatiia $v$ usloviiakh konvergentsii rossiiskikh standartov $k$ MSFO [Development of accounting and internal control of an enterprise's foreign trade activity in the conditions of convergence of Russian standards to IFRS]. Perm, West-Ural Institute of Economics and Law Publ., 2014. 232 p.

31. Sheshukova T.G., Shalaeva L.V. Strategicheskii upravlencheskii analiz vneshnei sredy [Strategic administrative analysis of the environment]. Perm, IPC Prokrost’’ Publ., 2015. 139 p.

32. Sheshukova T.G. Nauchnye osnovy kommercheskogo rascheta na predpriiatii [Scientific basis for the commercial calculation on the enterprise]. Vestnik Permskogo universiteta. Ser.: Ekonomika [Perm University Herald. Economy], 2010, no. 1, pp. 17-28.

33. Sheshukova T.G. Organizatsionnoe proektirovanie innovatsionnogo razvitiia hozyaistvennogo rashcheta na predpriiatii [Organization of designing, innovative development of the intraproductive "commercial calculation"]. Vestnik Permskogo universiteta. Ser.: Ekonomika [Perm University Herald. Economy], 2012, no. 4, pp. 24-27.
34. Sheshukova T.G. Kafedra ucheta, audita i ekonomicheskogo analiza: ot istokov do nashikh dnei [The Department of Accounting, Auditing and Economic Analysis from its origin to the present day]. Razvitie uchetno-analiticheskoi i kontrol'noi sistemy $v$ usloviiakh globalizatsii ekonomicheskikh processov [Development of accounting-analytical and control system under the conditions of economic processes globalization: collected scientific articles]. Perm, 2014, pp. 3-11.

35. Gorodilov M.A., Fetisova O.A. Goal Costing - Cost of Products (Works, Services) Calculation Methods Based on Systems Target Costing and Kaizen Costing in Sphere of Information Technologies. International Business Management, 2015, no. 9 (5), pp. 980-986.

36. Sheshukova T.G., Myhina E.R. The features of budgeting's construction for enterprises of electrical engineering industry. Of beaming and organization of effective functioning of innovation sphere of economy enterprise, industry, the complex. Salzburg, 2013, pp. 181-183.

37. Sheshukova T.G., Ponomareva S.V. The use of innovation technology software and forecasting of financial instruments. Of beaming and organization of effective functioning of innovation sphere of economy enterprise, industry, the complex. Salzburg, 2013, pp. 197-204.

38. Sheshukova T.G., Rybalko O.A. Assessment of system of internal control of the foreign trade activity. Formation, operation and development of enterprise structures in different forms, types and areas of economic activity: proceedings of the annual international conference. Budapest, 2013, pp. 50-54.

39. Sheshukova T.G., Rybalko O.A. Quality Assessment of the Internal Control of Foreign Trade Activity. World Applied Sciences Journal, 2013, no. 5 (26), pp. 606-609.

10.03.2016.

The date of the manuscript receipt:

\section{УЧЕТНО-АНАЛИТИЧЕСКИЕ И КОНТРОЛЬНЫЕ ПРОБЛЕМЫ УПРАВЛЕНИЯ ПРОИЗВОДСТВЕННЫМИ И ФИНАНСОВЫМИ РЕСУРСАМИ ПРЕДПРИЯТИЯ В УСЛОВИЯХ ГЛОБАЛИЗАЦИИ ЭКОНОМИЧЕСКИХ ПРОЦЕССОВ}

Т.Г. Шешукова, докт. экон. наук, профессор кафедры учета, аудита и экономического анализа Электронный адрес: sheshukova@psu.ru

Пермский государственный национальный исследовательский университет, 614990, Россия, г. Пермь, ул. Букирева, 15

В России всегда существовала весьма эффективная система научных школ, играющих важную роль в развитии общества. Научная школа одновременно реализует функции производства, распространения, защиты научных идей и обучение молодых ученых. Дается обзор теоретических и практических результатов, полученных в рамках научной школы кафедры «Учет, аудит и экономический анализ». Обзор охватывает период 2005-2015 гг. В центре внимания находятся аналитические проблемы теории и практики управления предприятием, учетные аспекты управления производственными и финансовыми ресурсами, теоретические и методические проблемы развития аудита и контроля. Целями исследования в рамках научной школы являются: разработка теоретических положений и практических рекомендаций по развитию финансового и управленческого учета; функцио- 
нально-аналитическое представление и обобщение теоретических основ системы регулирования аудиторской деятельности и определение направлений ее дальнейшего развития; совершенствование методики анализа экономического потенциала на основе компонентного подхода к его интегральной оценке; формирование теоретико-методологического аппарата, обеспечивающего трансформацию российской финансовой отчетности с учетом требований международных стандартов. Основу исследований составляют положения экономической теории, фундаментальные концепции философии, социальные гипотезы. Применялись системный и комплексный подходы, анализ и синтез, индукция и дедукция, экономико-математическое моделирование и программирование, статистические методы и методы социологических исследований. Представителями научной школы разработаны теоретические и методические положения, связанные с функционированием и развитием механизма финансового учета, системы управленческого учета, учитывающих организационно-экономические особенности предприятий и организаций нефтепродуктообеспечения, предприятий по производству электротехнической продукции, сельскохозяйственных организаций; развиты основы анализа экономического потенциала хозяйствующего субъекта; разработаны основы структурной трансформации основных форм финансовой отчетности в соответствии с международными стандартами; создана модель качественно-ориентированной системы регулирования аудиторской деятельности. Теоретические и методические выводы уточняют и развивают существующую учетно-аналитическую и контрольную концепции. Результаты исследований предназначены для широкого практического применения, представлялись в форме докладов на конференциях, а также нашли отражение в учебном процессе.

Ключевые слова: научная школа, стратегический анализ, оченка экономического потенциала, финансовый и управленческий учет, налоговый учет и контроль, международные стандарты финансовой отчетности, бухгалтерская экспертиза, коммерческий расчет, аудит, контроль.

\section{Please cite this article in English as:}

Sheshukova T.G. Problems of accounting, analysis and control in managing an enterprise's production and financial resources in the context of economic processes globalization // Vestnik Permskogo universiteta. Seria Ekonomika $=$ Perm University Herald. Economy. 2016. № 2(29). P. 32-53. doi: 10.17072/1994-99602016-2-32-53 